\title{
Pengembangan Media Belajar Komik Terhadap Motivasi Belajar Siswa
}

\author{
Ahmad Fadillah \\ Program Studi Pendidikan Matematika, Universitas Muhammadiyah Tangerang \\ ahmadfadillah@umt.ac.id
}

\begin{abstract}
INFO ARTIKEL
Riwayat Artikel:

Diterima: 15-02-2018

Disetujui: 16-03-2018

\section{Kata Kunci:}

Media belajar komik

Motivasi belajar siswa

ABSTRAK

Abstrak: Tujuan dari penelitian ini adalah untuk mengembangkan media belajar komik terhadap motivasi belajar siswa. Penelitian ini dilakukan di SMK Farmasi Tangerang 1 pada semester genap tahun ajaran 2016/2017. Metode yang digunakan adalah Research and Development (R\&D). Produk yang dihasilkan adalah media belajar komik matematika. Analisis data yang dilakukan dalam penelitian ini adalah: kelayakan media belajar komik dan keterbacaan komik yang dilakukan oleh para pakar serta motivasi belajar siswa. Dari hasil analisis data diperoleh rata-rata persentase $83 \%$ yang artinya dapat disimpulkan bahwa media belajar komik layak digunakan untuk bahan ajar.
\end{abstract}

\begin{abstract}
The purpose of this research is to develop a comic learning media on student learning motivation. This research was conducted in SMK Pharmacy Tangerang 1 in the even semester of academic year 2016/2017. The method used is Research and Development ( $R \& D)$. The resulting product is a comic learning media mathematics. Data and analysis conducted in this research are: the feasibility of comic learning media and comic readability done by the experts as well as student learning motivation. Based on the data analysis results obtained average percentage of $83 \%$ which means it can be concluded that the comic learning media is worth using for teaching material.
\end{abstract}

\section{A. LATAR BELAKANG}

Belajar merupakan kebutuhan manusia, dengan adanya proses belajar manusia mengalami suatu proses perubahan ke arah yang lebih baik lagi. Belajar juga merupakan hal terpenting dalam proses perkembangan manusia dari dahulu hingga kini. Slameto dalam (Djamarah, 2011) belajar adalah suatu proses yang dilakukan oleh individu untuk memperoleh perubahan perilaku baru secara keseluruhan, sebagai hasil dari pengalaman individu itu sendiri dalam berinteraksi dengan lingkungannya (h. 61). Hal ini menunjukkan bahwa, jika seseorang melakukan proses belajar dengan baik maka terjadilah suatu proses perubahan sebagai hasil dari proses belajar dalam jangka waktu tertentu. Perubahan yang dimaksud adalah yang sebelumnya tidak tahu menjadi tahu, tidak bisa menjadi bisa dan belum mampu menjadi mampu. Hal ini juga diperkuat oleh penyataan Gates, learning is the modification of behavior through experience and training yang artinya belajar adalah perubahan tingkah laku melalui pengalaman dan latihan (Prawira, 2012, h. 226). Artinya dengan adanya belajar yang dilakukan melalui pengalaman dan latihan, manusia mendapatkan suatu perubahan yang disebut hasil belajar. Menurut kelompok teori kognitif, belajar adalah proses pencapaian atau perubahan pemahaman (Insight), pandangan, harapan, atau pola berpikir (Abdurrahman, 2012, h. 24). Artinya dengan adanya proses belajar, seseorang akan mengalami suatu perubahan berupa pemahaman, pandangan, harapan ke arah yang lebih baik, dan pola berpikir yang lebih kreatif.

Dalam proses belajar, motivasi sangat diperlukan sebab seseorang yang tidak mempunyai motivasi dalam belajar tidak akan mungkin melakukan aktivitas belajar" (Djamarah, 2011, h.148). Dampak yang dapat ditimbulkan dari rendahnya motivasi belajar siswa adalah penurunan hasil belajar siswa yang menjadi tolak ukur keberhasilan pembelajaran. Menurut Uno (2007) hakikat motivasi belajar adalah dorongan internal dan eksternal pada siswa yang sedang belajar untuk mengadakan perubahan tingkah laku pada umumnya dengan beberapa indikator meliputi: Adanya hasrat dan keinginan berhasil; Adanya dorongan dan kebutuhan dalam belajar; Adanya harapan dan cita-cita masa depan; 
Adanya penghargaan dalam belajar; Adanya kegiatan yang menarik dalam belajar; Adanya lingkungan belajar yang kondusif sehingga memungkinkan seseorang siswa dapat belajar dengan baik (h.31).

Motivasi dibedakan menjadi dua jenis yaitu motivasi intrinsik dan ekstrinsik. Motivasi intrinsik adalah motivasi yang muncul dari diri seseorang tanpa adanya motivasi dari luar dirinya atau dari orang lain, sedangkan motivasi ekstrinsik adalah motivasi yang muncul dari luar dirinya. Menurut yasmin (2011) "Motivasi ekstrinsik merupakan kegiatan belajar yang tumbuh dari dorongan dan kebutuhan seseorang tidak secara mutlak berhubungan dengan kegiatan belajar sendiri. Motivasi ini tumbuh akibat dorongan dari luar diri seseorang seperti dorongan dari orang lain dan sebagainya" (h. 234). Jika seseorang tidak memiliki motivasi belajar dari dalam dirinya, maka diharapkan hal-hal dari lingkungan sekitarnya dapat memotivasinya dalam belajar. Beberapa bentuk motivasi belajar ekstrinsik menurut winkel (1989) dalam Yasmin (2011, h. 234) diantaranya adalah: belajar demi memenuhi kewajiban; belajar demi menghindari hukuman yang diancamkan; Belajar demi memperoleh hadiah material yang disajikan; belajar demi meningkatkan gengsi; belajar demi memperoleh pujian dari orang yang penting seperti orangtua dan guru; belajar demi tuntutan jabatan yang ingin diperoleh atau demi memenuhi persyaratan kenaikan pangkat atau golongan administratif. Sedangkan motivasi intrinsik Menurut Djamarah (2011) "yang dimaksud dengan motivasi intrinsik adalah motif-motif yang menjadi aktif atau berfungsinya tidak perlu dirangsang dari luar, karena dari dalam diri individu sudah ada dorongan untuk melakukan sesuatu" (h. 149). Artinya jika seseorang telah memiliki motivasi dari dalam dirinya, maka secara sadar ia akan melakukan suatu aktivitas atau kegiatan yang tidak memerlukan motivasi dari luar.

Motivasi yang akan diukur pada penelitian ini meliputi motivasi intrinsik dan ekstrinsik dengan indikator motivasi intrinsik meliputi: adanya hasrat dan keinginan berhasil, adanya dorongan dan kebutuhan dalam belajar, adanya harapan dan citacita masa depan. Sedangkan motivasi ekstrinsik meliputi: adanya penghargaan dalam belajar, adanya kegiatan yang menarik dalam belajar, adanya lingkungan belajar yang kondusif.

Dalam pelaksanaan pembelajaran di kelas, peran guru bukan hanya sebagai pendidik, guru juga berperan sebagai motivator yang diharapkan dapat meningkatkan motivasi siswa karena peningkatan dari prestasi belajar siswa tidak lepas juga ditentukan dengan tinggi atau rendahnya motivasi belajar siswa. Berdasarkan hasil observasi yang dilakukan di SMK Farmasi Tangerang 1, bahwa motivasi belajar siswa belum maksimal dikarenakan faktor pembelajaran yang konvensional yaitu kurang menariknya strategi pembelajaran yang digunakan guru dan media pembelajaran yang kurang bervariasi Pembelajaran yang dilakukan hanya menggunakan metode ceramah, kelompok, serta cenderung monoton dan membosankan. Sedangkan media pembelajaran yang digunakan hanya berupa buku paket dan Lembar Kerja Siswa (LKS). Hal ini ditandai dengan kurangnya motivasi belajar siswa yang dilihat dari kurangnya perhatian siswa saat pembelajaran berlangsung.

Salah satu cara yang dapat dilakukan guru dalam meningkatkan motivasi belajar siswa adalah dengan menggunakan media pembelajaran yang menarik dan efektif, sehingga siswa tertarik dan termotivasi dalam proses pembelajaran yang sedang berlangsung. Pada penelitian ini, media pembelajaran yang dipilih adalah media belajar komik karena visualisasi komik atau gambar-gambar yang ada di dalam komik sering di temui dalam kehidupan sehari-hari. Hal ini juga diperkuat dengan pernyataan Sudjana dan Rivai (2010) yang menyatakan antara 400 sampai 500 judul buku komik terjual dan kurang lebih 95 juta kopi terjual setiap bulannya yang diterjemahkan ke dalam 30 bahasa dan dibaca secara luas di lebih dari 100 negara (h. 63). Sedangkan berdasarkan penelitian yang dilakukan oleh Zain (2013) komik telah terbukti meningkatkan motivasi belajar siswa sehingga hasil belajar siswa menjadi maksimal di SMPN 1 Tempuran. Selain itu komik juga dapat meningkatkan minat baca siswa. Media visual komik berfungsi sebagai hiburan dan dapat dimanfaatkan untuk tujuan edukatif. Hal ini karena kedudukan komik yang makin berkembang kearah yang lebih baik dengan adanya kesadaran masyarakat akan nilai komersial dan nilai edukatif yang bisa dibawanya (Wahana Komputer, 2014, h. 4). Hal ini juga diperkuat dengan pernyataan Hurlock (1993) bahwa komik dapat membekali anak yang berkemampuan membaca yang terbatas mendapatkan suatu kegiatan membaca yang menyenangkan (Kurmawati, 2007, h. 123-124). Hurlock (1956) juga menerangkan bahwa alasan yang membuat anak senang membaca komik adalah karena komik mudah dibaca, bahkan anak dengan kemampuan baca rendah dapat memahami artinya dari gambar yang ada dalam komik (Rachmawati, 2013, h. 4).

Dengan adanya media belajar komik siswa juga dapat lebih mudah menggambarkan keadaan dan kasus-kasus matematika yang ada dalam kehidupan sehari-hari sehingga pembelajaran menjadi lebih menarik dan dapat lebih mudah dicerna oleh siswa. Media visual komik yang akan dikembangkan oleh peneliti adalah media cetak yang menggunakan bahasa dan istilah yang tidak sulit dipahami siswa karena kalimat yang digunakan di dalam media visual komik merupakan bahasa sehari-hari yang mudah dimengerti oleh siswa. Gambar dan paduan warna 
yang digunakan juga menarik yang dapat mengkomunikasikan informasi yang ada dengan baik dan memberikan pengalaman belajar yang menarik. Oleh karena itu, maka perlu diadakan penelitian tentang pengembangan media pembelajaran berupa buku atau bahan ajar yang berilustrasikan komik untuk meningkatkan motivasi belajar siswa. Oleh karena itu peneliti tertarik untuk melakukan penelitian dengan judul "Pengembangan Media Belajar Komik Terhadap Motivasi Belajar Siswa". Berdasarkan latar belakang masalah di atas, perumusan masalahannya adalah:

1. Bagaimana mengembangkan media belajar komik sebagai media pembelajaran?

2. Bagaimana motivasi belajar siswa SMK Farmasi Tangerang 1 setelah menggunakan media belajar komik?

\section{B. METODE PENELITIAN}

Tempat penelitian dilaksanakan di SMK Farmasi Tangerang 1, waktu penelitian dilaksanakan pada semester genap tahun ajaran 2016/2017. Model yang digunakan pada penelitian ini adalah metode penelitian dan pengembangan (Research and Development/ R\&D). Menurut Sugiyono (2012) "Research and Development adalah metode penelitian yang digunakan untuk menghasilkan produk tertentu, dan menguji keefektifan produk tersebut" (h. 297). Dalam penelitian ini, produk yang dihasilkan adalah media belajar komik matematika.

Berikut adalah rangkaian prosedur penelitian pengembangan media belajar komik terhadap peningkatan motivasi belajar siswa: observasi lapangan, pengumpulan data, desain komik dan penyusunan komik bahan ajar matematika, validasi desain komik oleh pakar media dan materi, revisi komik I, uji coba kelas terbatas, revisi komik II, uji coba kelas besar, analisis data, revisi komik III, komik final. Pengumpulan data yang dilakukan dalam penelitian ini adalah:

1. Kelayakan media visual komik

Diambil dari data validitas media visual komik dengan teknik penilaian berupa lembar validasi dari Badan Standar Nasional Pendidikan (BSNP) yang dinilai oleh pakar media, pakar materi dan pakar pembelajaran. Sebagai media visual, komik memiliki fungsi sebagaimana mestinya, yaitu menyampaikan pesan dan informasi (Aisyah, 2010). Selanjutnya komik akan di uji cobakan dalam skala kelas kecil menggunakan soal yang dapat mengukur keterbacaan komik dan angket respon siswa.

TABEL 1

PENILAIAN KEGRAFISAN MEDIA VISUAL KOMIK Aspek Indikator

Kegrafisan Media Visual Kesederhanaan

\begin{tabular}{ll}
\hline Komik & Keterpadanan \\
& Penekanan \\
& Keseimbangan \\
\hline
\end{tabular}

TABEL 2

PENILAIAN MATERI MEDIA VISUAL KOMIK

\begin{tabular}{|c|c|}
\hline Aspek & Indikator \\
\hline \multirow{3}{*}{$\begin{array}{l}\text { Komponen } \\
\text { kelayakan isi }\end{array}$} & Cakupan materi \\
\hline & Akurasi materi \\
\hline & Keingin tahuan \\
\hline $\begin{array}{l}\text { Komponen } \\
\text { kebahasaan }\end{array}$ & $\begin{array}{l}\text { Kesesuaian dengan } \\
\text { tingkat perkembangan } \\
\text { inteletual }\end{array}$ \\
\hline $\begin{array}{l}\text { Komponen } \\
\text { penyajian }\end{array}$ & $\begin{array}{l}\text { Komunikatif } \\
\text { Penyajian pembelajaran }\end{array}$ \\
\hline
\end{tabular}

\section{Keterbacaan komik}

Setelah komik valid menurut pakar selanjutnya komik di uji coba dalam uji coba kelas kecil guna mengetahui keterbacaan komik. Keterbacaan komik diukur dengan menggunakan angket keterbacaan media visual komik.

3. Motivasi belajar siswa

Data motivasi siswa diambil dengan menggunakan teknik angket. Berikut kisi - kisi motivasi belajar siswa.

TABEL 3

KISI -KISI MOTIVASI BELAJAR

\begin{tabular}{|c|c|c|c|c|}
\hline \multirow{2}{*}{ Aspek } & \multirow{2}{*}{ Indikator } & \multicolumn{2}{|c|}{ No. Item } & \multirow{2}{*}{ Total } \\
\hline & & $(+)$ & $(-)$ & \\
\hline \multirow{3}{*}{$\begin{array}{l}\text { motivasi } \\
\text { intrinsik }\end{array}$} & $\begin{array}{l}\text { adanya hasrat } \\
\text { dan keinginan } \\
\text { berhasil }\end{array}$ & $\begin{array}{c}1,3, \\
2\end{array}$ & & 3 \\
\hline & $\begin{array}{l}\text { adanya } \\
\text { dorongan dan } \\
\text { kebutuhan } \\
\text { dalam belajar }\end{array}$ & 4,5 & 6 & 3 \\
\hline & $\begin{array}{l}\text { adanya } \\
\text { harapan dan } \\
\text { cita-cita masa } \\
\text { depan } \\
\end{array}$ & 7,9 & 8 & 3 \\
\hline \multirow{3}{*}{$\begin{array}{l}\text { motivasi } \\
\text { ekstrinsik }\end{array}$} & $\begin{array}{l}\text { adanya } \\
\text { penghargaan } \\
\text { dalam belajar }\end{array}$ & $\begin{array}{l}10, \\
11, \\
12 \\
\end{array}$ & $\begin{array}{l}13, \\
14\end{array}$ & 5 \\
\hline & $\begin{array}{l}\text { adanya } \\
\text { kegiatan yang } \\
\text { menarik } \\
\text { dalam belajar }\end{array}$ & $\begin{array}{l}15, \\
16, \\
18\end{array}$ & $\begin{array}{l}17, \\
19\end{array}$ & 5 \\
\hline & $\begin{array}{l}\text { adanya } \\
\text { lingkungan } \\
\text { belajar yang } \\
\text { kondusif }\end{array}$ & 20 & 1 & \\
\hline
\end{tabular}

Validitas yang digunakan untuk instrumen pengukuran motivasi belajar siswa adalah validitas konstruk. Matondang menerangkan bahwa "validitas konstruk adalah validitas yang mempermasalahkan seberapa jauh butir-butir tes mampu mengukur apa yang benar-benar hendak diukur sesuai dengan 
konsep khusus atau definisi konseptual yang telah ditetapkan" (2009, h. 90). Dalam hal ini peneliti melakukan uji validitas konstruk dengan cara berkomunikasi dengan ahli yang kompeten dalam bidang pendidikan.

Kelayakan bahan ajar matematika diperoleh dari penilaian pakar materi dan pembelajaran menggunakan istrumen kelayakan buku teks pelajaran Matematika menurut BSNP serta instrumen penilaian kegrafisan oleh pakar media. Data validitas media visual komik dianalisis menggunakan rumus sebagai berikut (Arikunto, 2012, h. 272), yang kemudian selanjutnya dikategorikan sesuai kriteria kelayakan.

$$
\text { Nilai }=\frac{\text { Jumlah skor yang diperoleh }}{\text { Jumlah skor maksimal }} \times 100 \%
$$

TABEL 4

KRITERIA PENILAIAN VALIDASI KOMIK PAKAR

\begin{tabular}{cl}
\hline Persentase & \multicolumn{1}{c}{ Kriteria } \\
\hline $81 \%-100 \%$ & Sangat Layak \\
\hline $61 \%-80 \%$ & Layak \\
\hline $41 \%-60 \%$ & Cukup layak \\
\hline $21 \%-40 \%$ & Kurang layak \\
\hline$<20 \%$ & Tidak layak \\
\hline
\end{tabular}

Berdasarkan angket validasi komik oleh pakar tersebut makan dapat ditarik kesimpulan bahwa komik dianggap layak apabila skor penilaian aspek yang dinilai $\geq 61 \%$. Apabila skor penilaian aspek yang dinilai $<61 \%$ maka komik akan direvisi kembali.

Data respon siswa mengenai pembelajaran menggunakan media Visual komik sebagai bahan ajar matematika dianalisis menggunakan skala likert. Skala ini disusun dalam bentuk suatu pernyataan dan diikuti dengan lima respon yang menunjukkan tingkatnya (Sugiyono, 2012, h. 93), yaitu:

\section{TABEL 5}

\begin{tabular}{cl}
\multicolumn{2}{c}{ SKALA LIKERT VALIDASI } \\
\hline SS & Sangat setuju \\
\hline S & Setuju \\
\hline RG & Ragu-ragu \\
\hline TS & Tidak setuju \\
\hline STS & Sangat tidak setuju \\
\hline
\end{tabular}

Hasil respon siswa mengenai komik yang dikembangkan diambil melalui angket yang dianalisis dengan rumus sebagai berikut (Sugiyono, 2012, h. 95) dengan kriteria penilaian respon sebagai berikut (Arikunto \& Cepi, 2009), yaitu:

$$
\mathrm{N}=\frac{\mathrm{K}}{\mathrm{Nk}} \times 100 \%
$$

$\mathrm{N}=$ Jumlah persentase skor, $\mathrm{K}=$ Skor perolehan, $\mathrm{Nk}=$ Skor maksimal
TABEL 6

KRITERIA RESPON SISWA TERHADAP KOMIK

\begin{tabular}{cl}
\hline Persentase & \multicolumn{1}{c}{ Kriteria } \\
\hline $81 \%-100 \%$ & Sangat Layak \\
\hline $61 \%-80 \%$ & Layak \\
\hline $41 \%-60 \%$ & Cukup layak \\
\hline $21 \%-40 \%$ & Kurang layak \\
\hline$<20 \%$ & Tidak layak \\
\hline
\end{tabular}

Berdasarkan angket respon siswa tersebut makan dapat disimpulkan bahwa media visual komik layak digunakan apabila skor penilaian aspek yang dinilai $\geq$ 61\%. Data keterbacaan media visual komik dianalisis menggunakan rumus:

$$
\text { Nilai }=\frac{\text { Jumlah score yang diperoleh }}{\text { Jumlah score maksimal }} \times 100 \%
$$

Persentase yang diperoleh selanjutnya dikategorikan sesuai kriteria kelayakan menurut Savinainen dan Scott (2012) dalam (Widyaningtyas, 2013, h. 28):

TABEL 7

KRITERIA KETERBACAAN KOMIK

\begin{tabular}{|c|c|}
\hline Nilai dalam persen & Keterangan \\
\hline$\overline{\mathrm{x}}<30 \%$ & Rendah \\
\hline $30 \% \leq \overline{\mathrm{x}} \leq 70 \%$ & Sedang \\
\hline$\overline{\mathrm{x}}>70 \%$ & Tinggi \\
\hline
\end{tabular}

Untuk mengetahui motivasi belajar siswa digunakan angket, (Arikunto, 2012, h. 94) yaitu merubah data kualitatif menjadi kuantitatif dengan beberapa kategori, kemudian menjumlahkan jumlah skor yang diperoleh masing-masing siswa. Selanjtnya menentukan kriteria motivasi siswa menggunakan penilaian tiga kategori, "Tinggi", "Sedang" dan "Rendah" sesuai dengan kelompok skor (Arikunto, 2009, h. 271). Rentangan skor dibagi menjadi tiga sama besar.

TABEL 8

SKOR ANGKET MOTIVASI BELAJAR SISWA

\begin{tabular}{lcc}
\hline \multirow{2}{*}{\multicolumn{1}{c}{ Pilihan Jawaban }} & \multicolumn{2}{c}{ Skor } \\
\cline { 2 - 3 } & $\begin{array}{c}\text { Pernyataan } \\
\text { Positif }\end{array}$ & $\begin{array}{c}\text { Pernyataan } \\
\text { Negatif }\end{array}$ \\
\hline STS (Sangat Tidak Setuju) & 1 & 5 \\
\hline TS (Tidak Setuju) & 2 & 4 \\
\hline KA (Kurang Setuju) & 3 & 3 \\
\hline S (Setuju) & 4 & 2 \\
\hline SS (Sangat Setuju) & 5 & 1 \\
\hline
\end{tabular}

TABEL 9

KRITERIA MOTIVASI BELAJAR SISWA

\begin{tabular}{lc}
\hline \multicolumn{1}{c}{ Kriteria } & Skor \\
\hline Tinggi & $68-101$ \\
\hline Sedang & $34-67$ \\
\hline Rendah & $0-33$
\end{tabular}




\section{HASIL DAN PEMBAHASAN}

Pada penelitian ini, validasi desain komik dinilai berdasarkan penilaian oleh tiga pakar yaitu: pakar media, pakar materi dan pakar pembelajaran. Ketiga pakar tersebut adalah orang-orang yang ahli pada bidangnya masing-masing. Ketiga pakar tersebut berpendapat bahwa komik layak digunakan sebagai media pembelajaran dengan hasil penilaian sebagai berikut:

1. Hasil penilaian pakar media, dilihat dari komponen kegrafisan yang meliputi kesederhanaan, keterpaduan, penekanan dan keseimbangan. Penilaian media visual komik mendapat hasil 83\% dengan kriteria Sangat Layak.

2. Hasil penilaian pakar materi dan pakar pembelajaran

TABEL 10

HASIL PENILAIAN PAKAR

\begin{tabular}{llcc}
\hline \multirow{2}{*}{ No. } & Komponen & \multicolumn{2}{c}{ Persentase } \\
\cline { 3 - 4 } & & $\begin{array}{c}\text { Pakar } \\
\text { Materi }\end{array}$ & $\begin{array}{c}\text { Pakar } \\
\text { Pembelajaran }\end{array}$ \\
\hline 1. & Kelayakan & $82 \%$ & $80 \%$ \\
2. & isi & $80 \%$ & $78 \%$ \\
3. $\quad$ Kebahasaan & $83 \%$ & $79 \%$ \\
& Penyajian & $81,67 \%$ & $79 \%$ \\
\hline Rata-rata & Sangat & Layak \\
\hline persentase & Layak & \\
\hline
\end{tabular}

Rata-rata hasil penilaian media visual komik oleh pakar materi mendapat hasil $81,67 \%$ sedangkan berdasarkan hasil penilaian yang dilakukan oleh pakar pembelajaran media visual komik mendapatkan hasil 79\% dengan kriteria "Layak". Namun perlu dilakukan beberapa revisi sesuai saran dari ahli adalah sebagai berikut:

TABEL 11

REVISI MEDIA VISUAL KOMIK

\begin{tabular}{cll} 
No. & \multicolumn{1}{c}{ Halaman } & Bagian Yang Direvisi \\
\hline 1. & Cover depan & $\begin{array}{l}\text { Perlu ditambahkan } \\
\text { tujuan pembuatan } \\
\text { komik dan nama } \\
\text { pengarang komik. }\end{array}$ \\
\hline 2. & $\begin{array}{l}\text { Sesudah Cover } \\
\text { depan dan } \\
\text { sebelum masuk } \\
\text { kedalam cerita }\end{array}$ & $\begin{array}{l}\text { Pengenalan tokoh dan } \\
\text { character. }\end{array}$ \\
\hline 3. & $\begin{array}{l}\text { Halaman 6,10, } \\
\text { dan 12 }\end{array}$ & $\begin{array}{l}\text { Rumus perlu di tulis } \\
\text { dengan jelas. }\end{array}$ \\
\hline
\end{tabular}

Selanjutnya komik yang telah dinilai dan di revisi sesuai dengan saran dari pakar media, pakar materi dan pakar pembelajaran di perbanyak kemudian diuji cobakan pada Skala kecil.

3. Hasil uji coba skala kecil dilakukan di kelas XII sebanyak 10 orang siswa. Siswa dipilih secara acak dari kelas XII. Data dari uji coba skala kecil ini berupa data keterbacaan media visual komik dan data respon siswa mengenai pembelajaran dengan menggunakan komik matematika.

TABEL 12

DATA KETERBACAAN MEDIA VISUAL KOMIK

\begin{tabular}{|c|c|c|c|}
\hline No. & Pernyataan & $\%$ & Kriteria \\
\hline 1. & $\begin{array}{l}\text { Materi yang disajikan di } \\
\text { dalam media visual komik } \\
\text { sangat jelas sehingga saya } \\
\text { mudah untuk } \\
\text { mempelajarinya. } \\
\text { Fakta yang digunakan } \\
\text { sebagai contoh }\end{array}$ & 78 & Tinggi \\
\hline 2. & $\begin{array}{l}\text { adalah aktivitas kegiatan } \\
\text { sehari-hari yang ada di } \\
\text { sekitar saya, sehingga } \\
\text { saya mudah mengerti } \\
\text { informasi yang ingin } \\
\text { disampaikan media visual } \\
\text { komik. }\end{array}$ & 78 & Tinggi \\
\hline 3. & $\begin{array}{l}\text { Gambar yang ada di } \\
\text { dalam media visual komik } \\
\text { sesuai dengan cerita. }\end{array}$ & 80 & Tinggi \\
\hline 4. & $\begin{array}{lr}\text { Saya mudah memahami } \\
\text { gambar-gambar yang } \\
\text { terdapat pada media } \\
\text { visual komik. }\end{array}$ & 80 & Tinggi \\
\hline 5. & $\begin{array}{l}\text { Saya mudah membaca } \\
\text { tulisan yang ada di dalam } \\
\text { media visual komik } \\
\text { karena ukurannya sedang } \\
\text { dan tidak terlalu besar } \\
\text { atau kecil. }\end{array}$ & 75 & Tinggi \\
\hline 6. & $\begin{array}{l}\text { Warna yang digunakan di } \\
\text { dalam media visual komik } \\
\text { lebih menarik daripada } \\
\text { buku pelajaran yang } \\
\text { selama ini digunakan. }\end{array}$ & 76 & Tinggi \\
\hline 7. & $\begin{array}{l}\text { Media visual komik dapat } \\
\text { membuat saya mengingat } \\
\text { rumus lebih cepat } \\
\text { daripada buku pelajaran } \\
\text { yang selama ini } \\
\text { digunakan }\end{array}$ & 80 & Tinggi \\
\hline & Rata-rata & 78,14 & Tinggi \\
\hline
\end{tabular}

Berdasarkan tabel di atas ditunjukkan bahwa media visual komik memiliki skor keterbacaan sebanyak 78,14\% dengan kriteria keterbacaan "Tinggi". Hal ini menunjukkan bahwa media visual komik yang dikembangkan dapat terbaca dengan mudah oleh siswa. 
TABEL 13

RESPON SISWA KELAS KECIL

\begin{tabular}{|c|c|c|c|}
\hline No. & Pernyataan & $\%$ & Kriteria \\
\hline 1. & $\begin{array}{lr}\text { Pembelajaran } & \text { dengan } \\
\text { menggunakan media } \\
\text { visual komik pada } \\
\text { materi aritmatika sosial } \\
\text { sangat menarik. }\end{array}$ & 80 & Layak \\
\hline 2. & $\begin{array}{lcr}\text { Media } & \text { visual komik } \\
\text { yang } & \text { dikembangakan } \\
\text { dapat } & \text { mempermudah } \\
\text { dan membuat saya } \\
\text { cepat mengerti materi } \\
\text { yang sedang diajarkan. }\end{array}$ & 76 & Layak \\
\hline 3. & $\begin{array}{l}\text { Penggunaan tata bahasa } \\
\text { yang ada dalam media } \\
\text { visual komik mudah } \\
\text { dipahami } \\
\text { dimengerti. }\end{array}$ & 80 & Layak \\
\hline 4. & $\begin{array}{l}\text { Pembelajaran dengan } \\
\text { menggunakan media } \\
\text { visual komik pada } \\
\text { materi aritmatika sosial } \\
\text { memungkinkan saya } \\
\text { untuk belajar mandisi di } \\
\text { rumah/sekolah/ di } \\
\text { mana saja saya berada. }\end{array}$ & 78 & Layak \\
\hline 5. & $\begin{array}{lr}\text { Pembeljaran } & \text { dengan } \\
\text { menggunakan } & \text { media } \\
\text { visual } & \text { komik } \\
\text { matematika } & \text { mengubah } \\
\text { cara belajar saya. }\end{array}$ & 75 & Layak \\
\hline 6. & $\begin{array}{lrr}\text { Saya lebih } & \text { suka } \\
\text { membaca } & \text { media visual } \\
\text { komik } & \text { daripada } \\
\text { membaca } & \text { buku } \\
\text { pelajaran yang } & \text { biasa } \\
\text { digunakan } & \text { dalam } \\
\text { pembelajaran. } & \\
\end{array}$ & 76 & Layak \\
\hline 7. & $\begin{array}{lr}\text { Saya tidak mengalami } \\
\text { kesulitan } & \text { dalam } \\
\text { menggunakan } & \text { media } \\
\text { visual komik. } & \\
\end{array}$ & 78 & Layak \\
\hline & Rata-rata & 77,57 & Layak \\
\hline
\end{tabular}

Berdasarkan tabel di atas dapat diketahui bahwa hasil respon siswa terhadap komik yang telah digunakan memperoleh rata-rata persentase $77,57 \%$ dan menunjukkan kriteria "Layak" tanpa adanya revisi. Hal ini mengindikasikan bahwa media visual komik tersebut mendapat respon positif dari 10 orang siswa pada uji coba skala kecil dan telah layak untuk dilakukan uji coba pemakaian pada skala besar.

4. Hasil uji coba skala besar dilakukan di kelas XII yang berjumlah 30 orang. Data yang diperoleh dari uji coba skala besar adalah motivasi belajar siswa dan respon siswa terhadap pembelajaran menggunakan komik. Berdasarkan data yang diperoleh pada uji coba pemakaian komik pada skala besar, pembelajaran dengan menggunakan media visual komik terbukti menarik dan menyenangkan.

TABEL 14

RESPON SISWA KELAS BESAR

\begin{tabular}{|c|c|c|c|}
\hline No. & Pernyataan & $\%$ & Kriteria \\
\hline 1. & $\begin{array}{l}\text { Pembelajaran dengan } \\
\text { menggunakan media } \\
\text { visual komik pada materi } \\
\text { aritmatika sosial sangat } \\
\text { menarik. }\end{array}$ & $86 \%$ & $\begin{array}{l}\text { Sangat } \\
\text { Layak }\end{array}$ \\
\hline 2. & \begin{tabular}{lr}
\multicolumn{2}{l}{ Media visual komik yang } \\
dikembangakan dapat \\
mempermudah dan \\
membuat saya cepat \\
mengerti materi yang \\
sedang diajarkan.
\end{tabular} & $83 \%$ & $\begin{array}{l}\text { Sangat } \\
\text { Layak }\end{array}$ \\
\hline 3. & \begin{tabular}{lr}
\multicolumn{2}{l}{ Penggunaan tata bahasa } \\
yang ada dalam media \\
visual komik mudah \\
dipahami & dan \\
dimengerti. & \\
\end{tabular} & $83 \%$ & $\begin{array}{l}\text { Sangat } \\
\text { Layak }\end{array}$ \\
\hline 4. & $\begin{array}{lr}\text { Pembelajaran } & \text { dengan } \\
\text { menggunakan media } & \text { visual komik pada materi } \\
\text { aritmatika } & \text { sosial } \\
\text { memungkinkan saya } & \text { santuk belajar mandisi di } \\
\text { untumah/sekolah/ di mana } \\
\text { rumaha }\end{array}$ & $82 \%$ & $\begin{array}{l}\text { Sangat } \\
\text { Layak }\end{array}$ \\
\hline 5. & $\begin{array}{lr}\text { Pembeljaran } & \text { dengan } \\
\text { menggunakan } & \text { media } \\
\text { visual komik matematika } \\
\text { mengubah cara belajar } \\
\text { saya. }\end{array}$ & $81 \%$ & $\begin{array}{l}\text { Sangat } \\
\text { Layak }\end{array}$ \\
\hline 6. & $\begin{array}{l}\text { Saya lebih suka } \\
\text { membaca media visual } \\
\text { komik daripada } \\
\text { membaca buku pelajaran } \\
\text { yang biasa digunakan } \\
\text { dalam pembelajaran. }\end{array}$ & $81 \%$ & $\begin{array}{c}\text { Sangat } \\
\text { Layak }\end{array}$ \\
\hline 7. & $\begin{array}{lr}\text { Saya tidak mengalami } \\
\text { kesulitan } & \text { dalam } \\
\text { menggunakan } & \text { media } \\
\text { visual komik. } & \end{array}$ & $83 \%$ & $\begin{array}{l}\text { Sangat } \\
\text { Layak }\end{array}$ \\
\hline & Rata-rata & $83 \%$ & $\begin{array}{c}\text { Sangat } \\
\text { Layak }\end{array}$ \\
\hline
\end{tabular}

Hasil respon siswa kelas XII terhadap media visual komik menunjukkan rata-rata persentase sebesar 83\%. Hal ini menunjukkan bahwa hasil respon siswa mencapai kriteria sangat baik. Uji coba pemakaian media visual komik dalam skala besar menunjukkan bahwa media visual komik yang digunakan dalam pembelajaran telah efektif digunakan sehingga 
tahap revisi kedua tidak perlu dilakukan. Komik yang telah teruji adalah produk akhir dari rangkaian penelitian dan pengembangan.

\section{SIMPULAN DAN SARAN}

Berdasarkan tujuan penelitian dan hasil penelitian pengembangan media visual komik pada materi aritmatika sosial, dapat diperoleh kesimpulan sebagai berikut:

1. Validasi media komik mendapatkan skor $83 \%$ dengan kategori sangat layak digunakan

2. Validasi dari pakar materi dan pakar media pembelajaran diperoleh:

a. Pakar materi: rata-rata persentase $81,67 \%$ dengan kategori sangat layak digunakan

b. Pakar media pembelajaran: rata-rata persentase $79 \%$ dengan kategori layak digunaka, namun perlu dilakukan beberapa revisi

3. Pada uji coba skala kecil oleh 10 siswa untuk:

a. keterbacaan komik: diperoleh persentase rata-rata $78,14 \%$ dengan kategori tinggi

b. respon siswa: diperoleh persentase ratarata $77,57 \%$ dengan kategori layak, komik tidak perlu di revisi

4. Pada uji coba skala besar oleh 30 siswa untuk pencapaian motivasi belajar siswa yang tinggi sebesar $83 \%$ hal ini menunjukkan media visual komik layak digunakan sebagai bahan ajar.

\section{UCAPAN TERIMA KASIH}

Ucapan trima kasih yang sebesar-besarnya kepada semua pihak yang telah membantu selama proses penelitian ini, terutama kepada SMK Famrmasi Tangerang I yang telah memberikan waktu dan tempat, dan kepada para pakar yang telah bersedia memvalidasi serta merevisi bahan ajar ini.

\section{REFERENSI}

[1] Abdurrahman, M. (2012). Anak Berkesulitan Belajar. Jakarta: Rineka Cipta

[2] Aisyah, Siti; dkk. (2010). Perkembangan dan Konsep Dasar Pengembangan Anak Usia Dini. Jakarta: Universitas Terbuka

[3] Arikunto, S. (2012). Prosedur Penelitian Suatu Pendekatan Praktik. Jakarta: Rineka Cipta.

[4] Arikunto, Suharsimi dan Cepi Abdul Jabar, Safrudin. (2009). Evaluasi Program Pendidikan. Jakarta: Bumi Aksara.
[5] Hurlock, E.B. (1993). Psikologi Perkembangan Suatu pendekatan sepanjang rentang kehidupan (edisi kelima), Jakarta: Erlangga

[6] Hurlock, E.B, (1956). Child Development. New York: McGraw-Hill Book Company, Inc.

[7] Matondang, Zulkifli. (2009). Validitas dan Reliabilitas Suatu Instrumen Penelitian. Jurnal Tabularsa PPS UNIMED, 6(1), 87-97

[8] Nana Sudjana dan Ahmad Rivai. (2010). Media Pengajaran Penggunaan dan Pembuatannya. Bandung: Sinar Baru Algensindo Offset.

[9] Purwa Atmaja Prawira. (2012). Psikologi Pendidikan dalam Perspektif Baru. Yogyakarta: Ar-Ruz Media.

[10] Savinainen \& Scott. (2002). The Force Concept Inventory. A Tool for Monitoring Student Learning, Physics Education.

[11] Uno, Hamzah B. (2007). Model Pembelajaran Menciptakan Proses Belajar Mengajar yang Kreatif dan Efektif. Jakarta: Bumi Aksara

[12] Zain, Muhammad. (2014). Wahana Komputer: Mudah Membuat Animasi dengan Adobe Flash CS5. Yogyakarta: Penerbit Andi, 